THE OPINION OF MANKIND 



\title{
The Opinion of Mankind
}

\author{
SOCIABILITY AND THE \\ THEORY OF THE STATE \\ FROM HOBBES TO SMITH
}

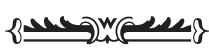

Paul Sagar 
Copyright (C) 2018 by Princeton University Press

Published by Princeton University Press,

41 William Street, Princeton, New Jersey o8540

In the United Kingdom: Princeton University Press,

6 Oxford Street, Woodstock, Oxfordshire OX20 1TR

press.princeton.edu

All Rights Reserved

ISBN 978-0-691-17888-2

Library of Congress Control Number: 2017945419

British Library Cataloging-in-Publication Data is available

This book has been composed in Miller

Printed on acid-free paper. $\infty$

Printed in the United States of America

109876554321 
To Bob Hargrave, who taught me the art of philosophy, and István Hont, who showed me the importance of history. 
As is the osprey to the fish, who takes it

By sovereignty of nature. First he was

A noble servant to them; but he could not

Carry his honours even: whether 'twas pride,

Which out of daily fortune ever taints

The happy man; whether defect of judgment,

To fail in the disposing of those chances

Which he was lord of; or whether nature,

Not to be other than one thing, not moving

From the casque to the cushion, but commanding peace

Even with the same austerity and garb

As he controll'd the war; but one of these-

As he hath spices of them all, not all,

For I dare so far free him-made him fear'd,

So hated, and so banish'd: but he has a merit,

To choke it in the utterance. So our virtues

Lie in the interpretation of the time:

And power, unto itself most commendable,

Hath not a tomb so evident as a chair

To extol what it hath done.

One fire drives out one fire; one nail, one nail;

Rights by rights falter, strengths by strengths do fail.

(WILLIAM SHAKESPEARE, THE TRAGEDY OF CORIOLANUS) 